\title{
DIFFERENCES IN CONSIDERING THE OPERATIONAL RISK DURING THE STRATEGY IMPLEMENTATION PROCESS - CASE STUDY OF CLASSICAL AND VISIONARY STRATEGIC APPROACH*
}

\author{
Joanna Radomska**
}

\begin{abstract}
Background. The article describes the issue of considering the operational risk, its identification and analysis, in the strategy implementation stage. It was decided to present the practices used by the companies that are representing the biggest percentage of the sample - a classical and a visionary strategic approach and to analyse their similarities as well as the differences.
\end{abstract}

Research aims. Its purpose is to present and analyse the differences in the process of risk consideration in organisations representing different types of strategic approach - classical and visionary.

Methodology. The conducted research was based on the qualitative research method using case studies. It is a part of a broader research on operational risk associated with the strategy implementation, conducted on 150 companies listed on the Warsaw Stock Exchange, operating in different industries. The sample was chosen because the presence on the stock exchange requires formulating precise strategies and associated strategic objectives, as well as reporting the progress in their implementation. It may be assumed that the companies listed on the WSE pay much attention to controlling the strategy implementation process and the issue of risk associated is an important aspect.

Key findings. The research results show that the two strategic approaches differ in analyzed aspects of operational risk management. Especially surprising is the level of their formalisation, contradictory to the initial assumptions. It was assumed that the visionary approach is more informal and based rather on the scenario planning, while the classical approach seem more formal and regular. The cases described showed the opposite characteristics of approaches.

\footnotetext{
* Project No. 2014/13/D/HS4/01425 was financed by the National Science Centre.

** Wrocław University of Economics. E-mail: joanna.radomska@ue.wroc.pl
} 
Keywords: operational risk, strategy implementation, classical and visionary strategic approach.

\section{INTRODUCTION}

The results of many studies confirm the importance of problems relating to strategy execution and a high percentage of organisations indicating unsatisfactory implementation outcomes. The causes of this phenomenon are attributed mainly to the ineffective transition of a development concept into the system of its implementation (Crittenden \& Crittenden, 2008). Owing to this, the catalogue of factors influencing the effectiveness of implementation activities is rather wide and encompasses elements of various categories which constitute the choices accompanying the implementation of the strategy devised (Wheelen $\&$ Hunger, 2011). They may be considered from the perspective of risk factors influencing the ineffectiveness of the process of development concept execution. On the other hand, it seems important to analyse the character of the strategy devised, which may determine not only implementation activities, but also the specific approach to the elements of risk and its quantification and elimination. The objective of this work is to present and analyse the differences in the process of risk consideration in organisations of a classical and visionary strategic approach. The perspective of the analysis conducted was limited to operational risk related to internal elements of the organisation. It was defined as the possibility of a loss connected with an occurrence of organisational factors which negatively influence the strategy implementation process. The internal perspective was chosen based on the research results confirming that organisational elements significantly influence the results of strategy implementation (Mankins and Steele, 2005, p. 4; Desroches et al., 2014). The strategic approach was devised on the basis of a classification proposed by Reeves, Haanaes and Sinha (2015a, p. 7). 


\section{STRATEGY NATURE AND ITS INFLUENCE ON RISK PERCEPTION - A LITERATURE REVIEW}

A great deal of empirical and theoretical research relates to the factors considered in the process of strategy formulation (Kunc \& Morecroft, 2010). In particular, these aspects concentrate on a regular analysis of changes in the environment and a scrupulous study of the system of internal factors. The coherence and effectiveness of that system influence the final result of the entire process (Huy, 2012). The comprehensiveness of these analyses, their scope and usage are considered as a basic point for creating the development concept, as well as deciding about the resources and skills necessary for defining the unique competence of an organisation (Fiss, 2011). Different strategies thus result from the way in which an enterprise perceives the expansiveness of concepts devised and the operational character of their execution (Lin et al., 2014, s. 1979). Strategic approach is also a derivative of shaping relations with the competition (Allred et al., 2011) as well as the perception of co-operation and relationships with stakeholders as an element affecting the nature of the strategy (Fjeldstad et al., 2012).

On the other hand, the degree of success of a particular strategy execution understood as the effectiveness of the implementation process (without analysing the context of results achieved) depends substantially on the internal factors (organisational) and their adjustment to the character of the concept devised (Song et al., 2007). It is also indicated that there is a need for correlating 3 elements: the nature of the strategy implementation process, the concept itself as well as the type of environment in which it is performed. It means accepting the strategic approach cohesive at the stage of formulation and realisation of the development concept (Reeves, 2012a, p. 4). This results from the fact that each type of strategy requires individual configuration of the structure, processes, and systems (Galbraith, 2002), composing a defined organisational system which constitutes a key element of the strategy execution concept (Zabaedah et al., 2013, p. 21).

It is possible to differentiate many concepts detailing various classifications of strategic approach types. The studies show that most frequently they are based on the different activities undertaken as a reaction to the changes of the environment (Miles and Snow concept, 2003), including practices used by the competition (classification 
according to Porter, 1980) (Slater \& Olson, 2000). The issues that are analysed concern the competitive position, expansiveness of the strategy devised and potential development opportunities (Puiu \& Stanciu, 2008 , p. 99). Some of the research indicates also a similarity within the strategic practices (Aragón-Sánchez \& Sánchez-Marín, 2005). In this paper the concept presented by Reeves, Haanaes and Sihna (2015b, pp. 4-7) was adopted. On this basis, five types of strategic approach may be differentiated. They are specified according to the possibility of shaping the environment and predicting its changes. Within this division, five strategic approaches may be distinguished:

- classical (realised in an industry of a foreseeable and slow pace of change, the basis of which is a detailed, consistently executed plan and thus the key activities encompass analysis, prediction, and optimalisation);

- $\quad$ adaptive (relating to an environment of difficulty in prediction where the advantage is temporary and the recipe for its maintenance is a continuous adjustment to the ongoing changes also by experimenting and seizing opportunities);

- visionary (within which both prediction and shaping of the environment are possible. Those actions are demanding and require creativity and inclination to risk-taking);

- shaping (executed with a lack of opportunity for prediction of environmental changes, but having an influence on their course by undertaking advance measures, which requires an extended relational network and building competitive advantage based on co-operation with other stakeholders);

- renewal (based on an approach within which it is necessary to renew and reshape the development direction to date owing to unusually difficult competitive conditions, which may require decisive and bold actions).

It is worth mentioning, that these typologies are only a theoretical concept which, in practice, could be varied and unique as a consequence of the specifics of the organisations. As long as the strategies themselves are similar to each other, the opportunities for achieving competitive advantage are determined by the manners of their implementation (Schneier et al., 1991, p. 281). The results of many studies confirm the existing correlation between results achieved and the degree of strategy execution (Chaimankong \& Prasertsakul, 2012, p. 11), while there is a lack of connection between the results and nature of the 
strategy executed (Hatten et al., 2004. These differences relate above all to the provision of access to certain resources (configurations of which are also heterogeneous), process design, controlling system or the approach to risk consideration. The last of the factors mentioned is linked with the approach to creation and execution of the strategy, especially with the degree of formality and regularity of practices performed. It may be assumed accordingly that practices used present the same degree of regularity and formality within the process of identification, analysis, monitoring and reaction to the occurrence of risk factors (independently of their nature).

One of the approaches to risk factors consideration is the connection of their occurrence with a particular activity which may take different forms, starting from eliminating the negative effects, through the creation of options and reaction scenarios, or merely analysing the causes of their incidence. The use of a specific procedure is a reflection of a wider management system within which particular processes and their scope, regularity, and degree of formality are devised (Reeves \& Deimler, 2011, p. 141). It can be presumed that the characteristics of the course of the formulation process and development concept execution translate into the characteristics of procedures used as a part of activities serving risk management, independently of their type. As the analysis of risk is not the main aim of the presented research, it is worth mentioning that risk was considered using a negative perspective (Jajuga \& Jajuga 2014, p. 98) of subjective nature.

\section{RESEARCH METHODOLOGY}

The research presented in the article was of a qualitative nature and based on the method of case study. It constitutes a fragment of a wider quantitative study relating to operational risk accompanying strategy execution, conducted on a sample of 150 public companies listed on the WSE. The general research sample was diversified in the size and the branch in which the activity is performed. In order to obtain more information on activities undertaken within the process of operational risk management accompanying strategy execution, in-depth interviews were conducted. The operational risk was defined as a set of internal factors. To describe and explore a business phenomenon within a real-life context, the descriptive, non-positivist approach 
was used. Exploratory research tends to follow this approach, as the objective is to select a sample with a particular purpose in mind, rather than to produce statistical generalisations of findings (Remenyi et al., 1998). The appropriateness of this research method for the present work is supported by Yin (2003). According to him, a case study is an empirical enquiry used to investigate a contemporary phenomenon within its real-life context when the boundaries between it and the context are not clearly evident, and multiple sources of evidence can be used. Unstructured interviews were conducted with executives of each firm responsible for strategy creating and implementing. Reliability was ensured on the constructs extracted. The sample size included four companies. It was decided that the practices of two companies representing the highest percentage of the sample studied - of a classical and visionary strategy nature - would be presented in order to juxtapose, analyse, and indicate certain regularities. The source materials obtained from the entities were also analysed. This allowed to obtain more detailed information regarding the practices and activities undertaken as part of the optimisation of the influence of operational risk on the effects of strategic activities achieved. The discussed results are not, however, of a general nature and may not be interpreted with reference to a wider group. Nevertheless, they are a source of information on management practices, which allowed to draw the theoretical contributions.

\section{CASE STUDY}

The first of the cases described concerns a large enterprise of the sports industry selling on the retail market. It represents a visionary approach to strategy and so may both predict the changes in its environment and shape it. The industry in which the business activity is conducted has difficult competitive conditions due to a high number of competitors and the dynamism of changes. The changes, however, are predictable within a .5-1 year perspective, which requires analyses and detailed reports, using various sources of information available. The potential for creation of ongoing changes by the enterprise described results from two causes. First of all, due to a share of German capital, information analysed and employed comes from Western markets. All trends and phenomena observed there, are further implemented on 
the Polish market, which often means activities undertaken ahead of the competition. Secondly, beyond standard retail activity, services accompanying some product categories are being developed. For that reason, it is possible to perform current activities serving market development by offering services complementary to basic product categories and reacting to trends observed, as well as shaping their desired direction. An example of this type of activity are the testing centres used by runners where shoes may be chosen, tested, and measured professionally, and where professional advice may be obtained. This is aimed at influencing the decision-making process and creating customer needs.

The concept of the strategy has a horizon of three to five years and is vaguely formalised. It is also described by a set of strategic aims (around 10) devised in a segmental cross section (for particular assortments), with their execution closely monitored and analysed regularly. The control is carried out on two levels - sales and operational. The first covers an analysis of variations from the levels assumed, while the second one concerns other factors influencing unsatisfactory results. The frequency of evaluation is rather high (even within a week). For that reason, internal risk elements are quickly diagnosed and eliminated. This means extended analytics including precise evaluation of the existence of particular factors, although it rarely refers to the determination of their probability. Predictions devised are of a short- and long-term nature, yet responses to the variations observed are made on an ongoing basis. The level of tolerance for the emergence of operational risk (taken into account sectional formulation of the objectives) is also defined and linked to the motivational system devised. Within this range no activities aiming at the elimination of the risks observed are undertaken. Strategic aims are also considered and are the basis of further decisions concerning potential modifications. Reporting, on the other hand, is fairly detailed and formal. It is worth mentioning that the process of strategy execution is considered satisfactory and because of that the modifications are applied only to the strategy itself. For that reason there is a plan of changing the structure of the business model, which also requires modifying the constituent processes. In the case described, the operational risk connected with the internal factors, is far more easier to diagnose and eliminate than that of an external nature. The highest level of risk is observed in human resources, which results from employee turnover as well as low level 
of knowledge concerning the development concept and connection of current activities with its execution. Despite the fact that the strategy itself is announced every six months, reaching the middle level of the organisational structure, and knowledge and feedback from shop managers is used in the process of its formulation (consultations were conducted, meetings at which the desired development direction as well as internal and external risks are discussed), the activities do not ensure the engagement of low-ranking employees. A low level of risk, however, is diagnosed for the area of leadership due to a high level of and continually improved competences among the executives as well as their long experience in the company, and as a consequence, knowledge possessed. Nor do resources pose a threat as they are properly adjusted to the implementation measures, although financial resources and their acquisition and increase are at the highest level of risk. Furthermore, the area of strategy execution measurements is defined as one of lower risks owing to the high number of indicators used, their systematisation, the regularity of their evaluation, interrelations, and coherence.

The second case examined concerns a classical approach to strategy for which the basis is a detailed analysis also including the prediction of changes affecting the environment associated with a lack of influence on their scope. The organisation studied represents a large enterprise from Subcarpathia which operates in the IT sector, perceived as dynamic and rapidly changing. Controlling those changes is therefore a great challenge also due to the high number of competitors operating on the local markets. The enterprise has thus adopted a concept of responding quickly to trends observed, the diagnosis of which is becoming a far more difficult task. Owing to this, the internal risk connected with the changeability of the environment is considered to be a collection of factors which may not be controlled, and the operations undertaken aim at limiting considerably and controlling operational risk, and thus that of an internal nature.

The basic activities are therefore based on the objectives defined in the strategy, which are further operationalised into particular processes. Communication of these relations is rather broad and includes managers of all levels as well as their subordinates. The monitoring of risk factors is possible owing to operations being executed simultaneously. The primary source of information are the results of detailed budget analyses performed on a monthly basis. The comparison of the estimate and the 
budget constitutes a set of data on the basis of which variations and their sources are defined and the measurement of their influence is feasible. In addition, internal orders are used as a tool to diagnose the level of execution of objectives based on the schedules of their realisation in particular sectors or units. This is, however, post factum activity and there is a lack of anticipation or measurement of potential risk factors which may have a negative influence on the strategy executed.

However, the levels of existing operational risk factors tolerance are defined, although their definition is not formal and is based on internal agreements. In some areas, it is necessary to accept certain buffers owing to potential estimation errors resulting from excessive enthusiasm and optimism for analyses conducted. The minor modifications to the original strategy are possible, because it is the implementation method which is revised rather than its content or directions. This relates, therefore, to the overview of processes executed - their stages, components or resources used and the revision of primary plans - their stages, horizons, or measures.

The analyses of internal operational risk factors are regular, which can also be observed in the case of other analyses, that may be recognised as a characteristic approach in the classical strategy executed. The factors of the highest operational risk apply to the area of employees and measures, while a lower level is indicated for resources and processes.

\section{CONCLUSION AND CONTRIBUTIONS}

The strategic approaches described differ mostly in the level of risk accompanying their strategic choices. The visionary approach requires a significantly higher inclination towards risk resulting from the opportunity to shape the environment. On the other hand, it is important to marshal resources, plan thoroughly and implement correctly and thus to organise well the implementation process for visions devised (Reeves, 2012b, p. 3). This is, however, undoubtedly seen as a more informal one, based on the scenario planning. The classical approach is based on a traditional sequence of activities - analysis, formation of a plan (often detailed) and definition of its implementation. It may, therefore, seem more formal and regular. Table 1 presents an overall view of the aspects analysed. 
Table 1. Comparison of various aspects of the operational risk management process in enterprises of a visionary and classical strategic approach

\begin{tabular}{|c|c|c|}
\hline Aspect & Visionary strategic approach & $\begin{array}{l}\text { Classical strategic } \\
\text { approach }\end{array}$ \\
\hline $\begin{array}{l}\text { Frequency of revisions (in- } \\
\text { cluding analysis of operational } \\
\text { risk factor occurrence) }\end{array}$ & $\begin{array}{l}\text { high regularity (even within } \\
\text { a week) }\end{array}$ & monthly \\
\hline $\begin{array}{l}\text { Meticulousness of the con- } \\
\text { trolling the operational risk } \\
\text { factors }\end{array}$ & $\begin{array}{l}2 \text { levels (simultaneous activ- } \\
\text { ities - sales and operational } \\
\text { levels) }\end{array}$ & $\begin{array}{l}2 \text { levels (simultaneous } \\
\text { activities - the budget } \\
\text { level and internal orders) }\end{array}$ \\
\hline $\begin{array}{l}\text { Comprehensiveness of the } \\
\text { quantification processes and } \\
\text { analysis of operational risk } \\
\text { factors }\end{array}$ & $\begin{array}{l}\text { detailed, but concerns the } \\
\text { influence of risk factors and } \\
\text { not the probability of their } \\
\text { occurrence, a priori activity }\end{array}$ & $\begin{array}{l}\text { detailed, but concerns the } \\
\text { influence of risk factors } \\
\text { and not the probability } \\
\text { of their occurrence, post } \\
\text { factum activity }\end{array}$ \\
\hline $\begin{array}{l}\text { Horizon of the prediction of op- } \\
\text { erational risk factor occurrence }\end{array}$ & short- and medium-term & short-term \\
\hline $\begin{array}{l}\text { Frequency of reaction to opera- } \\
\text { tional risk factor occurrence }\end{array}$ & ongoing & within a month \\
\hline $\begin{array}{l}\text { Level of tolerance for opera- } \\
\text { tional risk factor occurrence }\end{array}$ & $\begin{array}{l}\text { defined in the sectional } \\
\text { objectives formulation }\end{array}$ & defined, but informal \\
\hline $\begin{array}{l}\text { Degree of formalisation of } \\
\text { operational risk factor occur- } \\
\text { rence reporting }\end{array}$ & formal activities & informal activities \\
\hline $\begin{array}{l}\text { Factors of high operational } \\
\text { risk level }\end{array}$ & employee area & $\begin{array}{l}\text { areas of employees and } \\
\text { measures }\end{array}$ \\
\hline $\begin{array}{l}\text { Factors of low operational risk } \\
\text { level }\end{array}$ & $\begin{array}{l}\text { areas of leadership, resourc- } \\
\text { es and measures }\end{array}$ & $\begin{array}{l}\text { areas of resources and } \\
\text { processes }\end{array}$ \\
\hline
\end{tabular}

Source: own work.

The overall view of management practices described shows that the two strategic approaches differ in particular aspects of operational risk management. Especially surprising is the level of their formalisation, contradictory to the initial assumptions. This encompasses the reporting process for operational risk factor occurrence, which is more formal for the organisations of a visionary approach to strategy. Similarly, this is determined in the case of the tolerance level for reactions taken at the occurrence of particular factors and is demonstrated in a differing determination of risk referring to the area of measures. For the visionary organisation it is low, whilst for the classical, which approaches the strategic management process in a planned way, it is high. In both cases the area relating to employees indicated a high 
risk level. Also the meticulousness of the assessment of risk factor occurrence is similar and concerns two factors, although its scope and source of information are different. The frequency of revisions made and prediction horizon of operational risk factor occurrence are also alike. In the case of a visionary strategy, however, the frequency of reactions to operational risk factor occurrence is higher and encompasses current activities, which results from the application of rather detailed monitoring systems for activities undertaken. It is interesting to compare, however, the processes of quantification and the analysis of operational risk factors, which in both cases do not include the probability of their occurrence, although for the visionary organisation they have a predicative character while in the classical they are carried out only after their occurrence.

As the objective of this work was to present and analyse the differences in the process of risk consideration in organisations of a classical and visionary strategic approach, the conclusions presented above are not of a general character. The main idea was to present the issues described and verify whether the theoretical assumptions are used in practice, which turned out to be different than expected. The major limitation of this study is the small number of case studies, which should be enlarged to guarantee reliability. This is a rather difficult process considering the sensitive information needed. Nonetheless, the study was able to cover two strategic approaches identified, which was only possible because the theoretical sampling procedure was used. However, it is important to emphasise that the cases described are not of a general nature and the aim of their presentation is not the drawing of conclusions for the activity of all organisations representing a certain strategic approach. However, the implications arising from their analysis constitute an interesting research insight requiring additional study. Further research should, therefore, focus on an analysis of the differences with regard to practices applied, in particular their formalisation, level of detailed description and frequency, as well as an attempt to grasp their repeatability in organisations of a certain size or operating in particular industries, which would require extended regional and subject analysis. All mentioned analyses would allow to present more detailed conclusions. 


\section{REFERENCES}

Allred, C., Fawcett, S., Wallin, C. \& Magnan, G. (2011). A dynamic collaboration capability as a source of competitive advantage. Decision Sciences, 42(1).

Aragón-Sánchez, A., Sánchez-Marín, G. (2005). Strategic orientation, management characteristics, and performance: A study of Spanish SMEs. Journal of Small Business Management, 43(3).

Chaimankong, M. \& Prasertsakul, D. (2012). Impact of strategy implementation on performance of generic strategy: Evidence from Thailand. The South East Asian Journal of Management, 6(1).

Crittenden, V. \& Crittenden, W. (2008). Building a capable organization: The eight levers of strategy implementation. Business Horizons, 51(4) July-August.

Desroches, D., Hatch, T. \& Lawson, R. (2014). Are 90\% of organizations still failing to execute on strategy? The Journal of Corporate Accounting \& Finance, March/April.

Fiss, P. (2011). Building better causal theories: A fuzzy set approach to typologies in organization research. Academy of Management Journal, 54(2).

Fjeldstad, Ø., Snow, C., Miles, R. \& Lettl, C. (2012). The architecture of collaboration. Strategic Management Journal, 33(6).

Galbraith, J. (2002). Designing Organizations. San Francisco: Jossey-Bass.

Hatten, K.J., James, W.L., \& Meyer, D.G. (2004). The Longevity of the Performance Effects of the miles and snow strategic archetypes: A ten-year perspective in US banking, International Journal of Management \& Decision Making, 5(2/3).

Huy, Q. (2012). How middle managers' group-focus emotions and social identities influence strategy implementation. Strategic Management Journal, 32(13).

Jajuga, K. \& Jajuga T. (2014). Inwestycje: instrumenty finansowe, aktywa niefinansowe, ryzyko finansowe, inżynieria finansowa. Warszawa: Wydawnictwo Naukowe PWN.

Kunc, M. \& Morecroft, J. (2010). Managerial decision making and firm performance under a resource-based paradigm. Strategic Management Journal, 31(11).

Lin, C., Tsai, H. \& Wu J. (2014). Collaboration strategy decision-making using the Miles and Snow typology. Journal of Business Research, 67.

Mankins, M. \& Steele, R. (2005). Turning great strategy into great performance, Harvard Business Review, July-August.

Miles, R. \& Snow, C. (2003). Organizational Strategy, Structure and Process. Stanford, CA: Stanford University Press.

Porter, M.E. (1980). Competitive Strategy. New York: Basic Books. 
Puiu, C. \& Stanciu, M. (2008). Some theoretical aspects concerning the strategies' definition and typology. Annals of the Univerisity of Petrosani, Economics, 8(2).

Reeves, M. (2012a). Does your strategy match your competitive environment? Harvard Business School, August 28.

Reeves, M. (2012b). Know which strategy style is right for your organization. Strategy Execution. Harvard Business Review, September 20.

Reeves, M. \& Deimler, M. (2011). Adaptability: The new competitive advantage. Harvard Business Review, July-August.

Reeves, M., Haanaes, K. \& Sinha J. (2015a). Your strategy needs a strategy. How to Choose and Execute the Right Approach. Boston, Massachusetts: Harvard Business Review Press.

Reeves, M., Haanaes, K. \& Sinha, J. (2015b). Navigating the Dozens of Different Strategy Options. Harvard Business Review, June 24.

Remenyi, D., Williams, B., Money, A. \& Swartz, E. (1998). Doing Research in Business and Management. London: Sage.

Schneier, C., Shaw, D. \& Beatty, R. (1991). Performance measurement and management. Human Resources Management, 30(3).

Slater, S. \& Olson, E. (2000). Strategy type and performance: The influence of sales force management. Strategic Management Journal, 21(8).

Song, M., Di Benedetto, C. \& Nason, W. (2007). Capabilities and financial performance: The moderating effect of strategic type. Journal of the Academy of Marketing Science, 35(1).

Wheelen, T. \& Hunger, J. (2011). Strategic Management and Business Policy Toward Global Sustainability, 13th Edition. Englewood Cliffs, NJ: Prentince Hall.

Yin, R. (2003). Case Study Research Design and Methods, 3rd ed. Applied social research methods series, 5, Thousand Oaks: Sage Publications.

Zabaedah, Y., Fontana, A. \& Afiff, A. (2013). Revisiting the miles and snow typology. Strategic path mediating business strategy and resource configuration for innovation. The South East Asian Journal of Management, 7(1). 


\title{
RÓŻNICE W UWZGLĘDNIANIU RYZYKA OPERACYJNEGO W TRAKCIE REALIZACJI STRATEGII W PRZYPADKU KLASYCZNEGO I WIZJONERSKIEGO PODEJŚCIA STRATEGICZNEGO
}

\begin{abstract}
Abstrakt
Tło badań. Artykuł opisuje tematykę uwzględniania ryzyka operacyjnego, jego identyfikacji i analizy w trakcie działań wdrożeniowych służących implementacji strategii. Zaprezentowane zostana działania podejmowane przez organizacje zaliczone do klasycznego i wizjonerskiego podejścia strategicznego.
\end{abstract}

Cel badań. Celem artykułu jest prezentacja i analiza różnic w uwzględnianiu ryzyka operacyjnego w trakcie realizacji strategii występujących w organizacjach, które charakteryzują się różnym typem realizowanej koncepcji rozwojowej.

Metodologia. Przeprowadzone badania mają charakter jakościowy i wykorzystuja metodę studium przypadków. Stanowią fragment szerszych badań dotyczących ryzyka operacyjnego towarzyszacego realizacji strategii, przeprowadzonych na próbie 150 przedsiębiorstw giełdowych. Próba badawcza była różnorodna z punktu widzenia wielkości podmiotów oraz branży, w której prowadzona jest działalność. Uzasadnieniem doboru próby badawczej był fakt, iż obecność na giełdzie wiąże się z koniecznością wyznaczania i precyzyjnego określania strategii i towarzyszących jej celów strategicznych, a także raportowania postępów w ich realizacji. Tym samym można domniemywać, że spółki notowane na GPW przywiązują dużą wage do kontrolowania procesu implementacji strategii, a tym samym ryzyko mu towarzyszące stanowi dla nich istotny aspekt funkcjonowania. Zdecydowano się na prezentację praktyk zarządzania wykorzystywanych przez przedsiębiorstwa reprezentujące największy odsetek wśród badanej próby - o klasycznym i wizjonerskim charakterze strategii w celu ich zestawienia i analizy, a także wskazania pewnych prawidłowości.

Wnioski. Wyniki badań pokazuja, że oba strategiczne podejścia różnią się w analizowanych aspektach zarządzania ryzykiem operacyjnym. Szczególnie zaskakujacy jest poziom ich formalizacji, sprzeczny z pierwotnymi założeniami. Założono, że podejście wizjonerskie jest bardziej nieformalne i opiera się raczej na planowaniu scenariuszowym, podczas gdy podejście klasyczne wydaje się bardziej formalne i regularne. Opisane przypadki wykazały przeciwną prawidłowość.

Słowa kluczowe: ryzyko operacyjne, implementacja strategii, klasyczne i wizjonerskie podejście strategiczne. 